\title{
Effects of Different Carbohydrate Sources on Alfalfa Silage Quality at Different Ensiling Days
}

\author{
Run Gao ${ }^{1}{ }^{\oplus}$, Bing Wang ${ }^{2}{ }^{\oplus}$, Tingting Jia ${ }^{2}$, Ying Luo ${ }^{1}$ and Zhu Yu ${ }^{1, *} \mathbb{D}$ \\ 1 College of Grassland Science and Technology, China Agricultural University, Beijing 100193, China; \\ gaorun@cau.edu.cn (R.G.); S20193040629@cau.edu.cn (Y.L.) \\ 2 College of Animal Science and Technology, China Agricultural University, Beijing 100193, China; \\ wangb@cau.edu.cn (B.W.); B20163040303@cau.edu.cn (T.J.) \\ * Correspondence: 02059@cau.edu.cn; Tel.: +86-010-62733414
}

Citation: Gao, R.; Wang, B.; Jia, T.; Luo, Y.; Yu, Z. Effects of Different Carbohydrate Sources on Alfalfa Silage Quality at Different Ensiling Days. Agriculture 2021, 11, 58. https://doi.org/10.3390/agriculture 11010058

Received: 23 November 2020

Accepted: 8 January 2021

Published: 12 January 2021

Publisher's Note: MDPI stays neutral with regard to jurisdictional clai$\mathrm{ms}$ in published maps and institutional affiliations.

Copyright: (C) 2021 by the authors. Licensee MDPI, Basel, Switzerland. This article is an open access article distributed under the terms and conditions of the Creative Commons Attribution (CC BY) license (https:// creativecommons.org/licenses/by/ $4.0 /)$.

\begin{abstract}
This study was evaluated the effects of different carbohydrate sources on the fermentation profiles, chemical compositions, and correlation of fermentation profiles and chemical compositions with water-soluble carbohydrate (WSC) of alfalfa (Medicago sativa) silage. Alfalfa was harvested at early flowering stage from the third cutting in September 2018, wilted to 32\% dry matter (DM) and chopped into 1-2 cm pieces. Treatments included the addition of pectin (PEC), starch (STA; powdered corn), molasses (MOL), and fructose (FRU), as well as distilled water as a control (CON). Afterward, $300 \mathrm{~g}$ of prepared alfalfa was packed into polyethylene bags, vacuumed, and sealed, after which they were stored at room temperature for 1, 3, 7, 15, and $30 \mathrm{~d}$. FRU and PEC additions resulted in desirable fermentation profiles and chemical compositions throughout the ensiling period. FRU and PEC rapidly decreased the $\mathrm{pH}$ and increased Fleig's point, exhibiting lower $\mathrm{pH}$ and higher Fleig's point from $3 \mathrm{~d}$ to the end of ensiling. Acetic acid (AA), propionic acid (PA) and ammonia nitrogen (AN) contents of FRU and PEC were lower at $30 \mathrm{~d}$ after ensiling. Higher lactic acid (LA) contents were found in FRU and PEC from $7 \mathrm{~d}$ to the end of ensiling and higher LA:AA ratios from $15 \mathrm{~d}$ to the end of ensiling. Butyric acid (BA) was not detected at any point during the ensiling period. Additives exhibited higher DM content from 7 to $30 \mathrm{~d}$ after ensiling. The WSC content decreased as the number of ensiling days increased and was stable from $15 \mathrm{~d}$ to the end of ensiling. PEC, STA, and FRU exhibited higher WSC than CON. FRU and PEC improved the fermentation quality throughout the ensiling period. Thus, FRU and PEC or related agricultural byproducts may offer alternative additives for improving the alfalfa silage fermentation profile.
\end{abstract}

Keywords: alfalfa; fructose; pectin; fermentation profile; chemical composition; water-soluble carbohydrate

\section{Introduction}

Alfalfa (Medicago sativa) is an important protein source in ruminant livestock production [1,2] because of its high nutritional value, protein content, digestibility, and concentrations of vitamins and minerals. However, the nutritional value of alfalfa hay may be lost in the production, transport and storage processes. Thus, alfalfa is commonly processed into alfalfa silage in many regions. However, it has a low concentration of water-soluble carbohydrate (WSC) and dry matter (DM) and high buffering capacity [3-5], it is not easy to ensile successfully. Therefore, ensiled alfalfa is prone to decomposition, deterioration, and extensive proteolysis. Thus, it is necessary to apply additives (sugars, acids or microbial additives) or improve the DM by wilting or mixing with other high DM content forages to increase the fermentation quality of alfalfa silage.

Microbial additives are commonly applied to alfalfa to improve the quality of alfalfa silages in recent research. It is reported that lactic acid bacteria (LAB) and LAB mixing with cellulase could improve the quality of alfalfa silage [6-11]. Moreover, other organic acids, such as malic or citric acids, can effectively improve silage fermentation quality and 
inhibit proteolysis in alfalfa silage [12-14]. Certain carbohydrate additives are applied to alfalfa to improve silage fermentation quality. Sucrose and molasses are commonly applied to alfalfa to improve the quality of ensiling alfalfa. However, lots of crop products or byproducts containing high carbohydrate concentrations that have not been found to apply to alfalfa to improve alfalfa fermentation quality. Tian et al. [15] reported that dried jujube powder and Lactobacillus plantarum had positive effects on alfalfa fermentation and nutrition. Powdered corn is rich in starch and other nutrients and can be obtained worldwide. It may improve the fermentation quality of ensiled alfalfa. Powdered corn is rarely applied to alfalfa to improve the alfalfa quality. Fruit juice and honey is abundant in fructose and is produced by many fruit juice manufacturers. It not only can be applied to alfalfa to improve fermentation quality and promote utilization of waste. In addition, pectin is widely existed in citrus and apple peels and may be easily digested for ruminants to improve rumen fermentation $[16,17]$. Supplementation of alfalfa with molasses, orange pulp, and Lactobacillus buchneri were studied by Besharati et al. [18] to investigate the in vitro DM digestibility and gas production. Although few carbohydrates resources have already been applied to improve alfalfa fermentation quality, but the effects of adding these to alfalfa silages are not clear.

Thus, we hypothesized that different carbohydrates additives can improve the fermentation and nutritional quality while having no negative effects on alfalfa silage. Pectin, powdered corn, molasses, and fructose are rich in carbohydrates which may improve the alfalfa silage quality. However, it is unclear whether the different carbohydrate additives selected could improve the fermentation quality and nutritional composition of alfalfa silage. Therefore, the objective of the current study is to determine the changes in fermentation characteristics and chemical composition of alfalfa silage when adding different carbohydrate sources on different ensiling durations.

\section{Materials and Methods}

\subsection{Silage Material and Ensiling}

Alfalfa (Gannong No.4) was harvested at the early flowering stage from the third cutting in September 2018, in Yanchi, Ningxia, China. Alfalfa was planted for approximately two years without the application of fertilizers or herbicides throughout cultivation. Approximately $80 \mathrm{~kg}$ alfalfa was harvested with a sickle by hand, leaving a $5 \mathrm{~cm}$ stubble. Three duplicates were detected to evaluate the DM of alfalfa, the DM was $21 \%$. After wilting for $1.5 \mathrm{~d}$, the DM increased to $32 \%$. Then, the alfalfa was immediately chopped into 1-2 cm pieces with a chopper (9Z-0.4, Jinniu Machinery Factory Rongyang, (Rongyang, Henan, China). Four additives were subsequently applied to the alfalfa, including pectin (PEC, $2 \%$ fresh matter (FM)) with 95\% DM content; starch (STA, powdered corn, 2\% FM) with $88 \%$ DM content; molasses (MOL, $2 \% \mathrm{FM}$ ) with $80 \%$ DM content; and fructose (FRU, $2 \% \mathrm{FM}$ ) with $95 \% \mathrm{DM}$ content. In order to spray easily onto the prepared alfalfa, MOL and FRU were dissolved with $2 \%$ distilled water to account for FM allow for them to be easily sprayed onto the prepared alfalfa. To be consistent with those of MOL and FRU, the same volume of distilled water was used in the PEC and STA treatments. At the same time, the same volume of distilled water was sprayed onto prepared alfalfa without additives as control (CON), and $300 \mathrm{~g}$ of mixed alfalfa was weighed and packed into polyethylene bag, vacuumed with a vacuum sealer, and stored at room temperature until opening. Fifteen duplicates were prepared of each additive treatment, and three duplicates of each treatment ( 3 duplicates $\times 5$ treatments) were opened and collected after 1,3, 7, 15, and $30 \mathrm{~d}$ ensiling. A total of 75 bags were prepared in present study. Moreover, three duplicates were preserved before ensiling the material.

The purity of PEC (technical grade) was $65 \%$, which was sourced from citrus, and it was purchased from Yuanye Biological (Shanghai, China). STA was purchased from Green Liangcang (Sanhe, Hebei, China). The sucrose concentration of MOL was $48 \%$ (provided by the manufacturer), and it was purchased from Rongxin Chemical Industry 
(Jinan, Shandong, China). The purity of FRU was $99 \%$, and it was purchased from Shanghai Zhanyun Chemical Co., Ltd. (Shanghai, China).

\subsection{Fermentation Profile and Chemical Composition}

At each ensiling day, 15 bags ( 3 duplicates $\times 5$ treatments) were opened and $20 \mathrm{~g}$ of each sample was collected and mixed with $180 \mathrm{~mL}$ distilled water, homogenized with a blender for $60 \mathrm{~s}$, and successively filtered with 4-layer nylon gauze and qualitative filter paper. The $\mathrm{pH}$ was determined immediately using a $\mathrm{pH}$ meter (Five Easy Plus FE28, Mettler Toledo Co., Ltd., Shanghai, China). The ammonia nitrogen (AN) concentration was determined according to the method of Broderick and Kang [19], and the organic acid concentrations, including lactic acid (LA), acetic acid (AA), propionic acid (PA), and butyric acid (BA), were analyzed via HPLC, as previously described [20].

The alfalfa silage samples before and after ensiling were dried in an oven (GZX9140MBE, Shanghai Boxun Co., Ltd., Shanghai, China) at $65^{\circ} \mathrm{C}$ for $48 \mathrm{~h}$ for DM measurement. The dried samples were ground in a hammer mill (FZ102, Test Instrument, Tianjin, China) to pass through a $1 \mathrm{~mm}$ sieve for further chemical analysis. The crude protein $(\mathrm{CP})$ was analyzed with an automatic Kjeldahl nitrogen apparatus (Kjeltec 2300 AutoAnalyzer, FOSS Analytical AB, Hoganas, Sweden) according to AOAC [21] standards. The contents of neutral detergent fiber (NDF) and acid detergent fiber (ADF) were determined as described by Van Soest et al. [22] in a fiber analyzer (A2000I, Ankom Technology, Macedon, NY, USA). Sodium sulfite and thermostable $\alpha$-amylase were used in the NDF analysis, and the results were expressed as DM content. The WSC content was measured by the anthrone method [23].

\subsection{Calculations}

The quality of the alfalfa silage was evaluated by Fleig's point index, which was calculated as follows [24]:

Fleig's point $=220+[(2 \times \% \mathrm{DM})-15]-40 \times \mathrm{pH}$

The relative feed value (RFV) index was estimated as follows [25]:

$\mathrm{RFV}=(\mathrm{DDM} \times \mathrm{DMI}) / 1.29$

$\mathrm{DDM}=$ Digestible dry matter $=88.9-(0.779 \times \% \mathrm{ADF})$

DMI $=$ Dry matter intake $(\%$ of $B W)=120 /(\% N D F)$

\subsection{Statistical Analyses}

The experiment was a completely randomized design with a $3 \times 5 \times 5$ ( 3 duplicates, 5 additives and 5 ensiling days) factorial arrangement. The ANOVA procedure of SAS 9.4 was used to elucidate the additive effects at each ensiling day and effect of the ensiling time of each treatment silage on the fermentation characteristics and chemical composition. Post hoc mean comparisons were compared with Duncan's multiple comparisons. For the chemical profile and fermentation quality, a scheme of time-repeated measurements was used to repeat the fermentation periods among each treatment. The GLM procedure of SAS was used to elucidate the effects of the additives, ensiling time and their interactions for each parameter during the entire ensiling duration. Significance was declared at $p \leq 0.05$. The R software package was utilized for correlation analysis between fermentation profiles and chemical compositions of alfalfa silages.

\section{Results}

\subsection{ChemicalCompositions of Alfalfa before Ensiling}

The $\mathrm{pH}$ and AN contents of alfalfa before ensiling were 6.02 and $1.06 \mathrm{~g} / \mathrm{kg}$ total nitrogen (TN), respectively. The DM content before ensiling was $318.5 \mathrm{~g} / \mathrm{kg}$, and the $\mathrm{CP}$, $\mathrm{NDF}, \mathrm{ADF}$, and WSC contents before ensiling were 194.4, 377.8, 285.2, and $53.5 \mathrm{~g} / \mathrm{kg} \mathrm{DM}$, respectively. Moreover, the Fleig's point and RFV were 27.91 and 164.3, respectively. 


\subsection{Fermentation Characteristics of Alfalfa after Different Durations of Ensiling}

The $\mathrm{pH}$ of alfalfa silages are shown in Figure 1. Significant effects were detected for additives, ensiling days and their interaction. The $\mathrm{pH}$ gradually decreased as the number of ensiling days increased for all treatments. All of the different carbohydrate sources exhibited a significant effect on the $\mathrm{pH}$ of alfalfa silage from 3-30 d of ensiling (Table 1, $p \leq 0.01)$. PEC and FRU treatments resulted in a lower $\mathrm{pH}$ than other treatments during 3-30 d after ensiling.

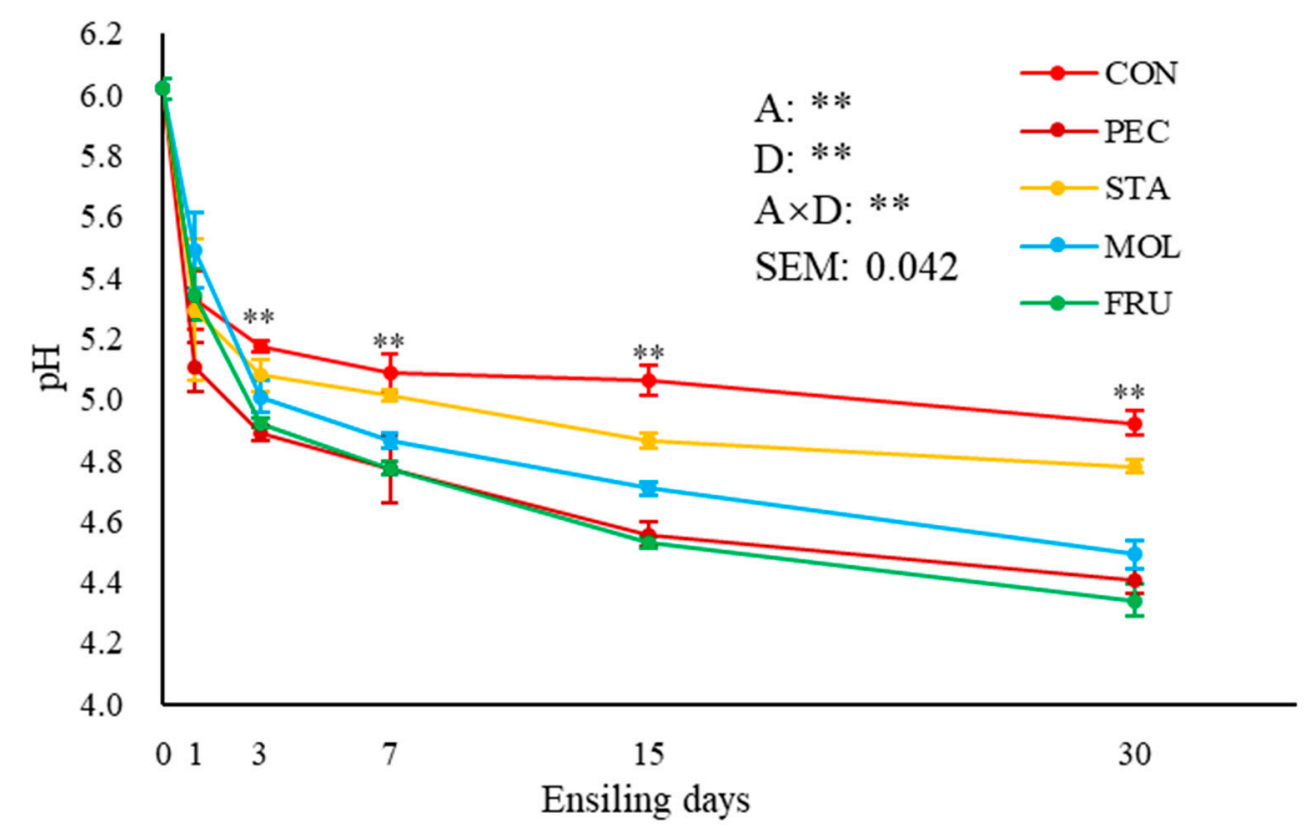

Figure 1. Effect of additives on $\mathrm{pH}$ as a function of the number of alfalfa ensiling days. $\mathrm{CON}$, control; PEC, pectin; STA, starch; MOL, molasses; FRU, fructose. A denotes significance of additives; D, denotes significance of ensiling days; $\mathrm{A} \times \mathrm{D}$ denotes the interactive effect between additives and ensiling days. SEM, standard error of means. The asterisks $(* * p 0.01)$ indicate the significance of additives and ensiling days and their interaction effects, and the difference at the specified ensiling day.

Table 1. Statistical analysis for the fermentation profile variables of alfalfa silage treated with different carbohydrate sources at different ensiling period.

\begin{tabular}{cccccc}
\hline \multirow{2}{*}{ Items } & \multicolumn{5}{c}{ Ensiling Day } \\
\cline { 2 - 6 } & $\mathbf{1}$ & $\mathbf{3}$ & $\mathbf{7}$ & $\mathbf{1 5}$ & $\mathbf{3 0}$ \\
\hline pH & 0.11 & $<0.01$ & $<0.01$ & $<0.01$ & $<0.01$ \\
LA & $<0.01$ & 0.05 & 0.01 & $<0.01$ & 0.01 \\
AA & 0.28 & 0.16 & 0.18 & 0.97 & 0.26 \\
PA & $<0.01$ & $<0.01$ & $<0.01$ & 0.22 & 0.01 \\
LA:AA ratio & $<0.01$ & 0.15 & 0.88 & 0.53 & $<0.01$ \\
AN & 0.44 & $<0.01$ & 0.72 & $<0.01$ & $<0.01$ \\
Fleig's point & 0.11 & $<0.01$ & $<0.01$ & $<0.01$ & $<0.01$ \\
\hline
\end{tabular}

Note: LA, lactic acid; AA, acetic acid; PA, propionic acid. AN, ammonia nitrogen.

Additives exhibited an effect on the LA concentration for each ensiling day (Table 1, $p \leq 0.05)$. The LA content increased gradually at the first three days after ensiling, then decreased at $7 \mathrm{~d}$ after ensiling, except for in the PEC treatment. PEC significantly exhibited higher LA content at 7, 15, and $30 \mathrm{~d}$ after ensiling compared with other treatments. The CON and STA treatments had lower LA contents than the other treatments at 7, 15, and $30 \mathrm{~d}$. 
Additives were not significant in terms of the AA content at each ensiling day, but the ensiling days and their interaction were significant (Table 2). At the last ensiling day, FRU and PEC exhibited a lower AA content than the other treatments but was not significant (Table $1, p>0.05$ ).

Table 2. The dynamics of organic acid concentrations of silage alfalfa during the entire ensiling period.

\begin{tabular}{|c|c|c|c|c|c|c|c|c|c|c|}
\hline \multirow{2}{*}{ Items $^{1}$} & \multirow{2}{*}{ Additives } & \multicolumn{5}{|c|}{ Ensiling Days } & \multirow{2}{*}{ SEM } & \multicolumn{3}{|c|}{$p$-Value } \\
\hline & & 1 & 3 & 7 & 15 & 30 & & A & D & $A \times \mathbf{D}^{2}$ \\
\hline \multirow{5}{*}{ LA (g/kg DM) } & $\mathrm{CON}$ & $6.45^{\mathrm{cB}}$ & $41.58^{\mathrm{aAB}}$ & $24.66^{\mathrm{bBC}}$ & $29.02^{b C}$ & $44.26^{\mathrm{aC}}$ & \multirow{5}{*}{1.151} & \multirow{5}{*}{$<0.001$} & \multirow{5}{*}{$<0.001$} & \multirow{5}{*}{$<0.001$} \\
\hline & PEC & $6.93^{\mathrm{dB}}$ & $32.49 \mathrm{cB}$ & $35.24 \mathrm{bcA}$ & $41.28^{\mathrm{bA}}$ & $58.32^{\mathrm{aA}}$ & & & & \\
\hline & STA & $24.37^{\mathrm{cA}}$ & $45.19^{\mathrm{aA}}$ & $23.00^{\mathrm{cC}}$ & $32.50 \mathrm{bBC}$ & $45.39 \mathrm{aC}$ & & & & \\
\hline & MOL & $24.88^{\mathrm{dA}}$ & $41.33^{\mathrm{bAB}}$ & $29.32 \mathrm{cdAB}$ & $36.81^{\mathrm{cb} A B}$ & $50.35^{\mathrm{aBC}}$ & & & & \\
\hline & FRU & $19.35^{\mathrm{dA}}$ & $46.04^{\mathrm{abA}}$ & $32.43^{\mathrm{cA}}$ & $40.71^{\mathrm{bA}}$ & $52.47^{\mathrm{aAB}}$ & & & & \\
\hline \multirow{5}{*}{$\mathrm{AA}(\mathrm{g} / \mathrm{kg} \mathrm{DM})$} & $\mathrm{CON}$ & $4.17^{\mathrm{b}}$ & $21.63^{\mathrm{a}}$ & $12.58^{a b}$ & $14.02^{\mathrm{a}}$ & $20.85^{a}$ & \multirow{5}{*}{0.706} & \multirow{5}{*}{0.607} & \multirow{5}{*}{$<0.001$} & \multirow{5}{*}{0.033} \\
\hline & PEC & 8.07 & 17.14 & 18.30 & 14.67 & 18.76 & & & & \\
\hline & STA & $7.58^{c}$ & $27.21^{\mathrm{a}}$ & $12.02^{c}$ & $13.97^{b c}$ & $20.46^{\mathrm{ab}}$ & & & & \\
\hline & MOL & $7.84^{\mathrm{c}}$ & $17.99^{a b}$ & $16.18^{\mathrm{ab}}$ & $15.47^{b}$ & $20.37^{\mathrm{a}}$ & & & & \\
\hline & FRU & $5.28^{\mathrm{b}}$ & $16.78^{a}$ & $18.18^{a}$ & $15.60^{\mathrm{a}}$ & $15.88^{a}$ & & & & \\
\hline \multirow{5}{*}{$\mathrm{PA}(\mathrm{g} / \mathrm{kg} \mathrm{DM})$} & $\mathrm{CON}$ & $0.00^{\mathrm{cB}}$ & $1.08^{\mathrm{cB}}$ & $1.76^{\mathrm{cC}}$ & $5.30^{b}$ & $12.70^{\mathrm{aAB}}$ & \multirow{5}{*}{0.522} & \multirow{5}{*}{$<0.001$} & \multirow{5}{*}{$<0.001$} & \multirow{5}{*}{0.087} \\
\hline & PEC & $0.00^{\mathrm{cB}}$ & $0.36^{\mathrm{cB}}$ & $3.70^{\mathrm{bB}}$ & $4.98^{b}$ & $10.69^{a B C}$ & & & & \\
\hline & STA & $0.00^{\mathrm{dB}}$ & $1.02^{\mathrm{cdB}}$ & $2.73^{\mathrm{cBC}}$ & $6.22^{b}$ & $12.75^{\mathrm{aAB}}$ & & & & \\
\hline & MOL & $2.58^{\mathrm{dA}}$ & $3.65^{\mathrm{dA}}$ & $5.09 \mathrm{cA}$ & $8.15^{b}$ & $14.95^{\mathrm{aA}}$ & & & & \\
\hline & FRU & $0.00^{\mathrm{dB}}$ & $0.00 \mathrm{~dB}$ & $2.27^{\mathrm{cC}}$ & $5.61^{b}$ & $9.13^{\mathrm{aC}}$ & & & & \\
\hline \multirow{5}{*}{ LA:AA ratio } & $\mathrm{CON}$ & $1.87^{\mathrm{B}}$ & 1.98 & 2.06 & 2.21 & $2.15^{\text {B }}$ & \multirow{5}{*}{0.082} & \multirow{5}{*}{$<0.001$} & \multirow{5}{*}{$<0.001$} & \multirow{5}{*}{$<0.001$} \\
\hline & PEC & $0.97^{\mathrm{cB}}$ & $1.91^{\mathrm{b}}$ & $2.01^{b}$ & $2.90^{\mathrm{a}}$ & $3.12^{\mathrm{aA}}$ & & & & \\
\hline & STA & $3.25^{\mathrm{aA}}$ & $1.74^{\mathrm{b}}$ & $1.92^{b}$ & $2.42^{b}$ & $2.24^{\mathrm{bB}}$ & & & & \\
\hline & MOL & $3.18^{\mathrm{aA}}$ & $2.40^{\mathrm{b}}$ & $1.81^{\mathrm{b}}$ & $2.38^{\mathrm{b}}$ & $2.50^{\mathrm{abB}}$ & & & & \\
\hline & FRU & $3.67^{\mathrm{aA}}$ & $2.79^{b}$ & $1.82^{\mathrm{c}}$ & $2.68^{\mathrm{b}}$ & $3.31^{\mathrm{aA}}$ & & & & \\
\hline
\end{tabular}

Note: No butyric acid was detected in any treatments during the ensiling duration. ${ }^{1}$ DM, dry matter. SEM, standard error of means. LA, lactic acid; AA, acetic acid; PA, propionic acid. CON, PEC, STA, MOL, and FRU, respectively, represent control, pectin, starch, molasses, and fructose. ${ }^{A-C}$ Means within a column with no common superscript differ $(p<0.05)$. ${ }^{a-d}$ Means within a row with no common superscript differ $(p<0.05) .{ }^{2} \mathrm{~A}, \mathrm{D}$, and $\mathrm{A} \times \mathrm{D}$ denote the significance of additives, ensiling days and their interactive effects, respectively.

Additives and ensiling days exhibited a significant effect on the PA content, but no interactive effect (Table 2). The MOL treatment exhibited a higher PA content during the entire ensiling period, and exhibited a significant effect at 1, 3, 7, and $30 \mathrm{~d}$ (Table 1, $p \leq 0.01)$. On the last day of ensiling, FRU and PEC exhibited a lower PA content than other treatments.

The LA:AA ratio of all treatments were significantly different at 1 and $30 \mathrm{~d}$ after ensiling (Table $1, p \leq 0.01$ ). At the first $7 \mathrm{~d}$ ensiling, LA:AA ratio of STA and MOL were dropped rapidly and, thereafter, increased slowly, reaching a value similar to that of $\mathrm{CON}$ (Table 2). The LA:AA ratio of CON did not significantly change throughout the ensiling period. However, the LA:AA ratio of PEC increased gradually and was similar to that of FRU on 15 and the last ensiling day.

Additives, ensiling days and their interaction exerted significant effects on the AN content of alfalfa silage (Figure 2). The AN content increased gradually as the ensiling time increased, and only MOL treatment decreased slightly at $15 \mathrm{~d}$ ensiling. Additives had a significant effect at 3, 15, and $30 \mathrm{~d}$ ensiling (Table 1, $p \leq 0.01$ ). FRU exhibited lower AN content at 15 and $30 \mathrm{~d}$ ensiling compared to that of the other treatments. The AN contents of CON and STA were higher than those of the other treatments on 15 and $30 \mathrm{~d}$ ensiling.

In addition, additives, ensiling days and their interaction exerted significant effects on the Fleig's point of alfalfa silage (Figure 3). Additives exhibited significant effects at 3, 7, 15, and $30 \mathrm{~d}$ after ensiling (Table $1, p \leq 0.01$ ). The PEC and FRU treatments of alfalfa silage significantly increased Fleig's point compared with other treatments. CON exhibited lower Fleig's point than the other treatments throughout the ensiling period. 


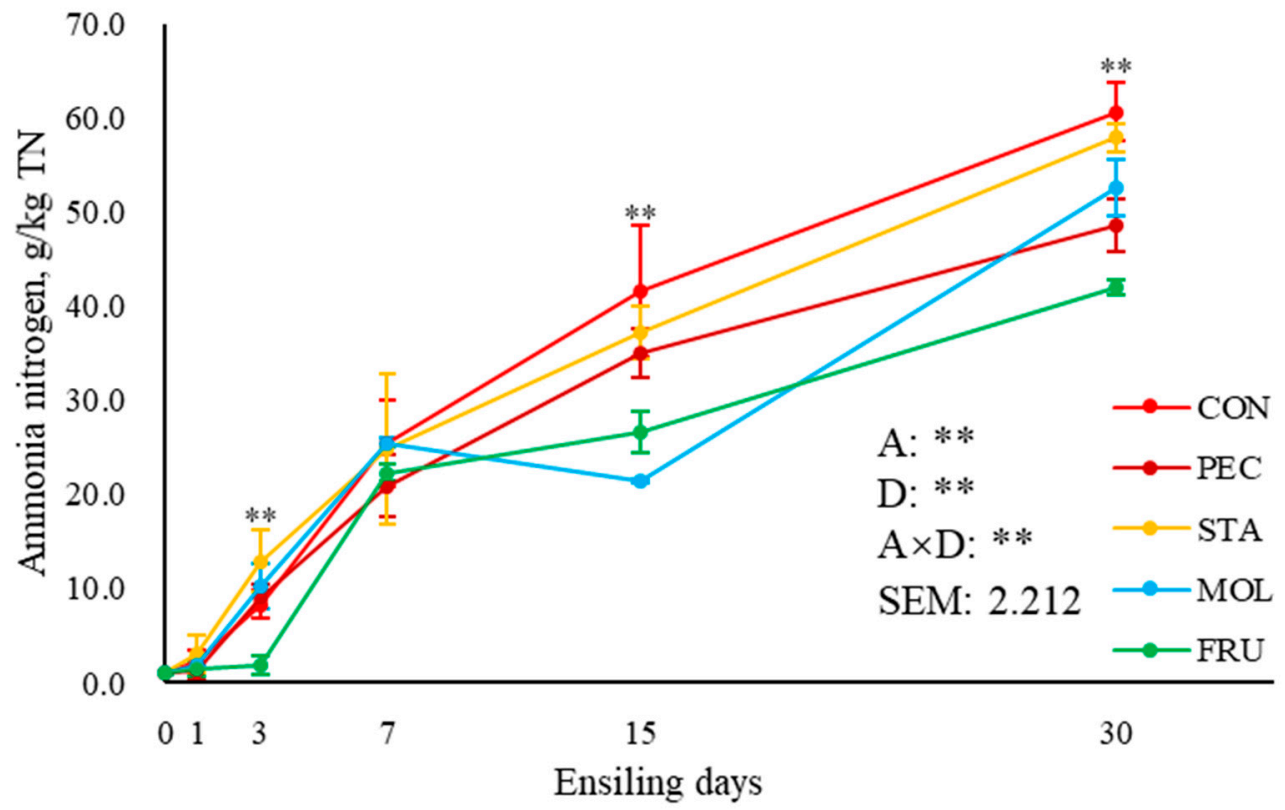

Figure 2. Effect of additives on the ammonia nitrogen (AN) content during ensiling of alfalfa. TN, total nitrogen; CON, control; PEC, pectin; STA, starch; MOL, molasses; FRU, fructose. A denotes significance of additives; $\mathrm{D}$, denotes significance of ensiling days; $\mathrm{A} \times \mathrm{D}$ denotes the interactive effect between additives and ensiling days. SEM, standard error of means. The asterisks $\left.{ }^{* *} p \leq 0.01\right)$ indicate the significance of additives and ensiling days and their interaction effects, and the difference at the specified ensiling day.

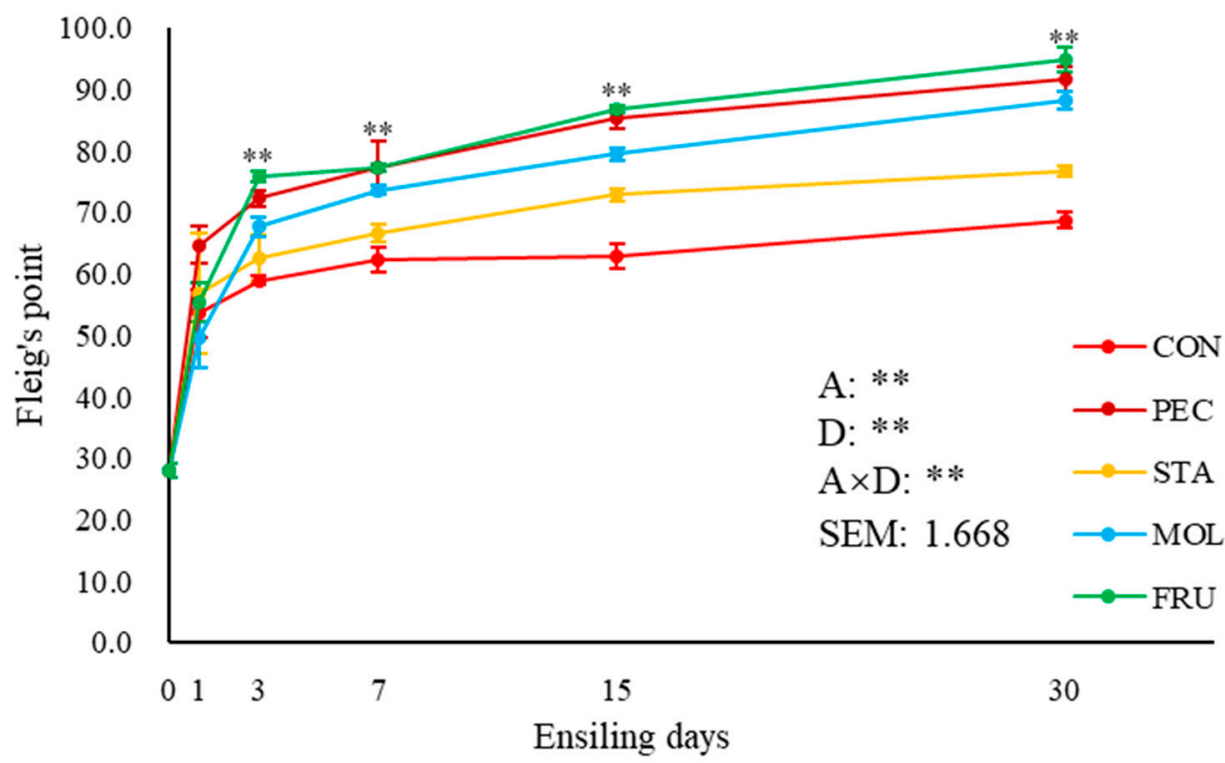

Figure 3. Effect of additives on the Fleig's point during ensiling of alfalfa. CON, control; PEC, pectin; STA, starch; MOL, molasses; FRU, fructose. A denotes significance of additives; D, denotes significance of ensiling days; $\mathrm{A} \times \mathrm{D}$ denotes the interactive effect between additives and ensiling days. SEM, standard error of means. The asterisks $\left.{ }^{* *} p \leq 0.01\right)$ indicate the significance of additives and ensiling days and their interaction effects, and the difference at the specified ensiling day.

\subsection{Chemical Composition of Alfalfa after Different Ensiling Days}

Additives, ensiling day and their interaction exerted significant effects on the DM, CP, ADF (Table 3), WSC contents (Figure 4), and RFV (Figure 5) of the alfalfa silage, but no interactive effect was observed for the NDF (Table 3). Additives exhibited a significant 
effect on the DM content at 1, 3, 7 15, and $30 \mathrm{~d}$ after ensiling (Table 4, $p \leq 0.01$ ). CON exhibited a lower DM content than the other treatments throughout the ensiling duration. At 7 and $15 \mathrm{~d}$ after ensiling, FRU exhibited lower $\mathrm{CP}$ content than the other treatments (Table $4, p \leq 0.01$ ). There were no differences among all treatments of $\mathrm{CP}$ content on the last ensiling day. FRU treatment exhibited lower NDF and ADF contents than the other treatments on $3 \mathrm{~d}$ after ensiling (Table $4, p \leq 0.01$ ). Additives exhibited significant effect on the WSC content of alfalfa silages on 1, 3, 7, and $30 \mathrm{~d}$ after ensiling (Table $4, p \leq 0.01$ ). The WSC content of all treatments decreased gradually as the number of ensiling days increased, except for those of MOL and FRU, which increased at $3 \mathrm{~d}$ after ensiling. The WSC content of all treatments stabilized from $15 \mathrm{~d}$ until the end of the ensiling period. Only at $3 \mathrm{~d}$, RFV exhibited differences among treatments (Table $4, p \leq 0.01$ ). CON exhibited a lower RFV compared with the other treatments throughout the ensiling process.

Table 3. The chemical composition of alfalfa before and after ensiling.

\begin{tabular}{|c|c|c|c|c|c|c|c|c|c|c|c|}
\hline \multirow{2}{*}{ Items $^{1}$} & \multirow{2}{*}{ Additives } & \multicolumn{6}{|c|}{ Ensiling Days } & \multirow{2}{*}{ SEM } & \multicolumn{3}{|c|}{$p$-Value } \\
\hline & & 0 & 1 & 3 & 7 & 15 & 30 & & $\mathbf{A}$ & D & $\mathbf{A} \times \mathbf{D}^{2}$ \\
\hline \multirow{5}{*}{$\mathrm{DM}(\mathrm{g} / \mathrm{kg})$} & $\mathrm{CON}$ & $318.5^{\mathrm{a}}$ & $308.0^{\mathrm{bB}}$ & $304.5^{\mathrm{CC}}$ & $303.8^{\mathrm{cB}}$ & $301.9^{\mathrm{cB}}$ & $303.5^{\mathrm{cB}}$ & \multirow{5}{*}{0.849} & \multirow{5}{*}{$<0.001$} & \multirow{5}{*}{$<0.001$} & \multirow{5}{*}{$<0.001$} \\
\hline & PEC & $318.5^{\mathrm{ab}}$ & $319.8^{\mathrm{aA}}$ & $314.2 \mathrm{bcB}$ & $315.5^{\mathrm{abcA}}$ & $313.2 \mathrm{cA}$ & $314.5^{b c A}$ & & & & \\
\hline & STA & $318.5^{\mathrm{a}}$ & $318.3^{\mathrm{aA}}$ & $303.9 \mathrm{bB}$ & $311.2^{\mathrm{aA}}$ & $312.3^{\mathrm{bA}}$ & $314.7 \mathrm{abA}$ & & & & \\
\hline & MOL & $318.5^{\mathrm{ab}}$ & $320.5^{\mathrm{aA}}$ & $315.5^{\mathrm{bB}}$ & $316.0^{\mathrm{abA}}$ & $314.1^{\mathrm{bA}}$ & $314.0^{\mathrm{bA}}$ & & & & \\
\hline & FRU & $318.5^{b c}$ & $320.6^{\mathrm{bA}}$ & $338.9^{\mathrm{aA}}$ & $316.3^{\mathrm{cA}}$ & $315.0^{\mathrm{cA}}$ & 317.0 bcA & & & & \\
\hline \multirow{5}{*}{$\mathrm{CP}(\mathrm{g} / \mathrm{kg} \mathrm{DM})$} & $\mathrm{CON}$ & $194.4^{\mathrm{b}}$ & $193.6^{\mathrm{b}}$ & $201.1^{\mathrm{a}}$ & $205.2^{\mathrm{aA}}$ & $201.2^{\mathrm{aA}}$ & $196.3^{\mathrm{b}}$ & \multirow{5}{*}{0.648} & \multirow{5}{*}{$<0.001$} & \multirow{5}{*}{$<0.001$} & \multirow{5}{*}{0.010} \\
\hline & PEC & $194.4^{\mathrm{ab}}$ & $191.0^{\mathrm{b}}$ & $198.1^{\mathrm{a}}$ & $198.0^{\mathrm{aAB}}$ & $194.1^{\mathrm{abBC}}$ & $196.4^{\mathrm{a}}$ & & & & \\
\hline & STA & $194.4^{b}$ & $190.5^{b}$ & $200.6^{\mathrm{a}}$ & $195.1^{\mathrm{bB}}$ & $192.5^{b C}$ & $194.4^{\mathrm{b}}$ & & & & \\
\hline & MOL & 194.4 & 190.7 & 198.9 & $199.6 \mathrm{AB}$ & $196.6^{\mathrm{B}}$ & 198.3 & & & & \\
\hline & FRU & 194.4 & 182.6 & 194.9 & $183.6^{\mathrm{C}}$ & $191.8^{\mathrm{C}}$ & 195.1 & & & & \\
\hline \multirow{5}{*}{ NDF(g/kg DM) } & $\mathrm{CON}$ & $377.8^{\mathrm{ab}}$ & $386.4^{\mathrm{a}}$ & $373.6^{\mathrm{abA}}$ & $354.6^{\mathrm{b}}$ & $381.8^{a b}$ & $389.3^{\mathrm{a}}$ & \multirow{5}{*}{2.283} & \multirow{5}{*}{0.002} & \multirow{5}{*}{$<0.001$} & \multirow{5}{*}{0.218} \\
\hline & PEC & 377.8 & 364.6 & $348.6^{\mathrm{B}}$ & 347.1 & 377.8 & 370.7 & & & & \\
\hline & STA & $377.8^{\mathrm{a}}$ & $368.5^{\mathrm{ab}}$ & $349.0^{\mathrm{bB}}$ & $346.4^{\mathrm{b}}$ & $368.0^{a b}$ & $391.3^{\mathrm{a}}$ & & & & \\
\hline & MOL & $377.8^{\mathrm{a}}$ & $355.0^{\mathrm{bc}}$ & $355.8 \mathrm{bcB}$ & $346.0^{c}$ & $370.8^{a b}$ & $364.8^{a b c}$ & & & & \\
\hline & FRU & $377.8^{\mathrm{a}}$ & $355.1^{\mathrm{ab}}$ & $319.7^{\mathrm{cC}}$ & $347.7^{\mathrm{b}}$ & $375.0^{\mathrm{a}}$ & $373.9^{\mathrm{a}}$ & & & & \\
\hline \multirow{5}{*}{$\mathrm{ADF}(\mathrm{g} / \mathrm{kg} \mathrm{DM})$} & $\mathrm{CON}$ & 285.2 & 290.3 & $288.3^{\mathrm{A}}$ & 277.7 & 282.2 & 292.1 & \multirow{5}{*}{1.614} & \multirow{5}{*}{$<0.001$} & \multirow{5}{*}{$<0.001$} & \multirow{5}{*}{0.002} \\
\hline & PEC & 285.2 & 274.1 & $266.1^{\text {B }}$ & 269.8 & 280.8 & 278.5 & & & & \\
\hline & STA & 285.2 & 278.9 & $273.9^{\text {В }}$ & 263.5 & 276.3 & 288.3 & & & & \\
\hline & MOL & 285.2 & 270.3 & $277.5^{\mathrm{AB}}$ & 270.2 & 277.3 & 277.9 & & & & \\
\hline & FRU & $285.2^{\mathrm{a}}$ & $272.2^{\mathrm{a}}$ & $229.8^{\mathrm{bC}}$ & $267.5^{\mathrm{a}}$ & $274.0^{\mathrm{a}}$ & $284.5^{\mathrm{a}}$ & & & & \\
\hline
\end{tabular}

Note: ${ }^{1} \mathrm{DM}$, dry matter; CP, crude protein; NDF, neutral detergent fiber; ADF, acid detergent fiber. SEM, standard error of means. CON, PEC, STA, MOL and FRU, respectively, represent control, pectin, starch, molasses and fructose. A-C Means within a column with no common superscript differ $(p<0.05) .{ }^{\mathrm{a}-\mathrm{c}}$ Means within a row with no common superscript differ $(p<0.05) .{ }^{2} \mathrm{~A}, \mathrm{D}$, and $\mathrm{A} \times \mathrm{D}$ denote the significance of additives, ensiling days and their interactive effects, respectively.

Table 4. Statistical analysis for the chemical composition variables of alfalfa silage treated with different carbohydrate sources at different ensiling period.

\begin{tabular}{cccccc}
\hline \multirow{2}{*}{ Items $^{\mathbf{1}}$} & \multicolumn{5}{c}{ Ensiling Day } \\
\cline { 2 - 6 } & $\mathbf{1}$ & $\mathbf{3}$ & $\mathbf{7}$ & $\mathbf{1 5}$ & $\mathbf{3 0}$ \\
\hline $\mathrm{DM}$ & $<0.01$ & $<0.01$ & $<0.01$ & $<0.01$ & $<0.01$ \\
$\mathrm{CP}$ & 0.08 & 0.33 & 0.01 & $<0.01$ & 0.18 \\
NDF & 0.23 & $<0.01$ & 0.94 & 0.56 & 0.37 \\
ADF & 0.29 & $<0.01$ & 0.69 & 0.69 & 0.43 \\
WSC & $<0.01$ & $<0.01$ & $<0.01$ & 0.07 & $<0.01$ \\
RFV & 0.26 & $<0.01$ & 0.90 & 0.69 & 0.37 \\
\hline
\end{tabular}

Note: ${ }^{1}$ DM, dry matter; CP, crude protein; NDF, neutral detergent fiber; ADF, acid detergent fiber; WSC, water-soluble carbohydrates; RFV, relative feed value. 


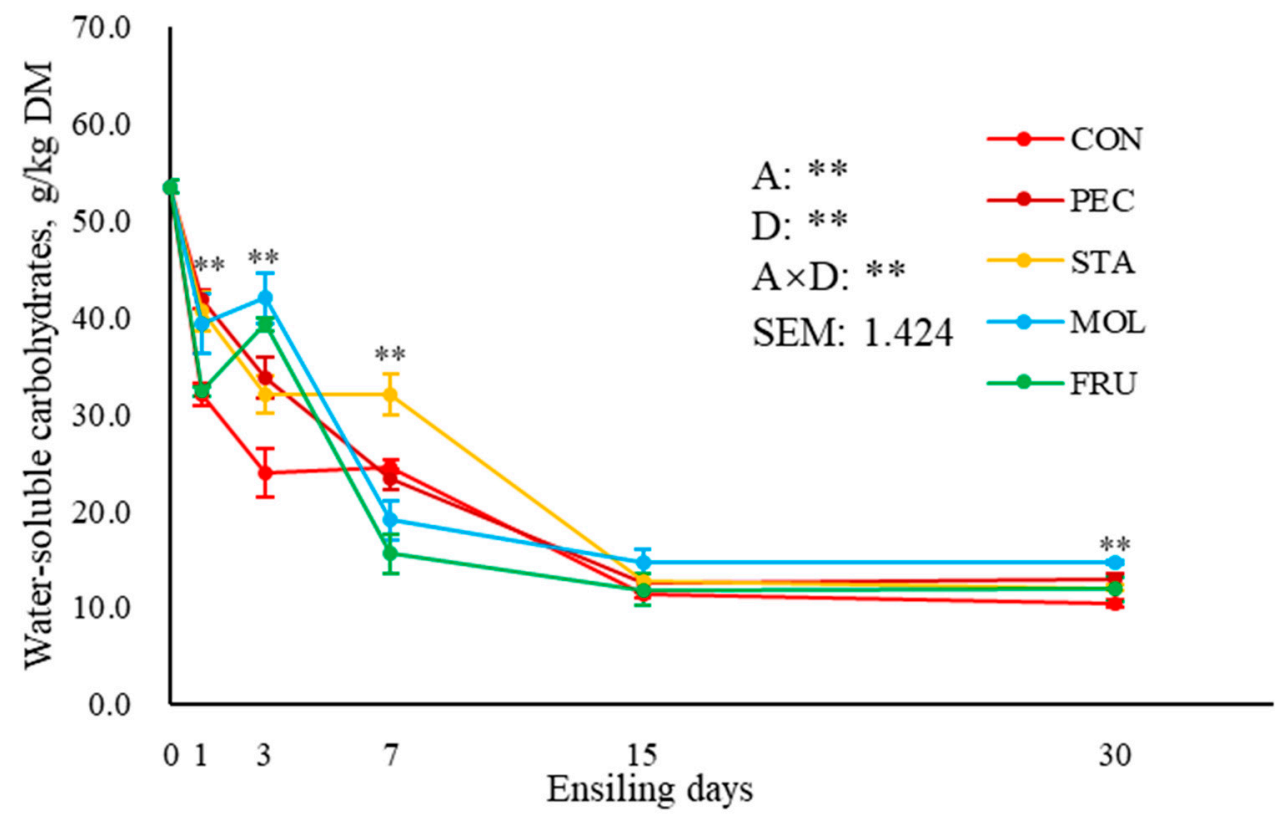

Figure 4. Effect of additives on the water-soluble carbohydrates (WSC) content during ensiling of alfalfa. DM, dry matter; CON, control; PEC, pectin; STA, starch; MOL, molasses; FRU, fructose. A denotes significance of additives; D, denotes significance of ensiling days; $\mathrm{A} \times \mathrm{D}$ denotes the interactive effect between additives and ensiling days. SEM, standard error of means. The asterisks $\left({ }^{* *} p \leq 0.01\right)$ indicate the significance of additives and ensiling days and their interaction effects, and the difference at the specified ensiling day.

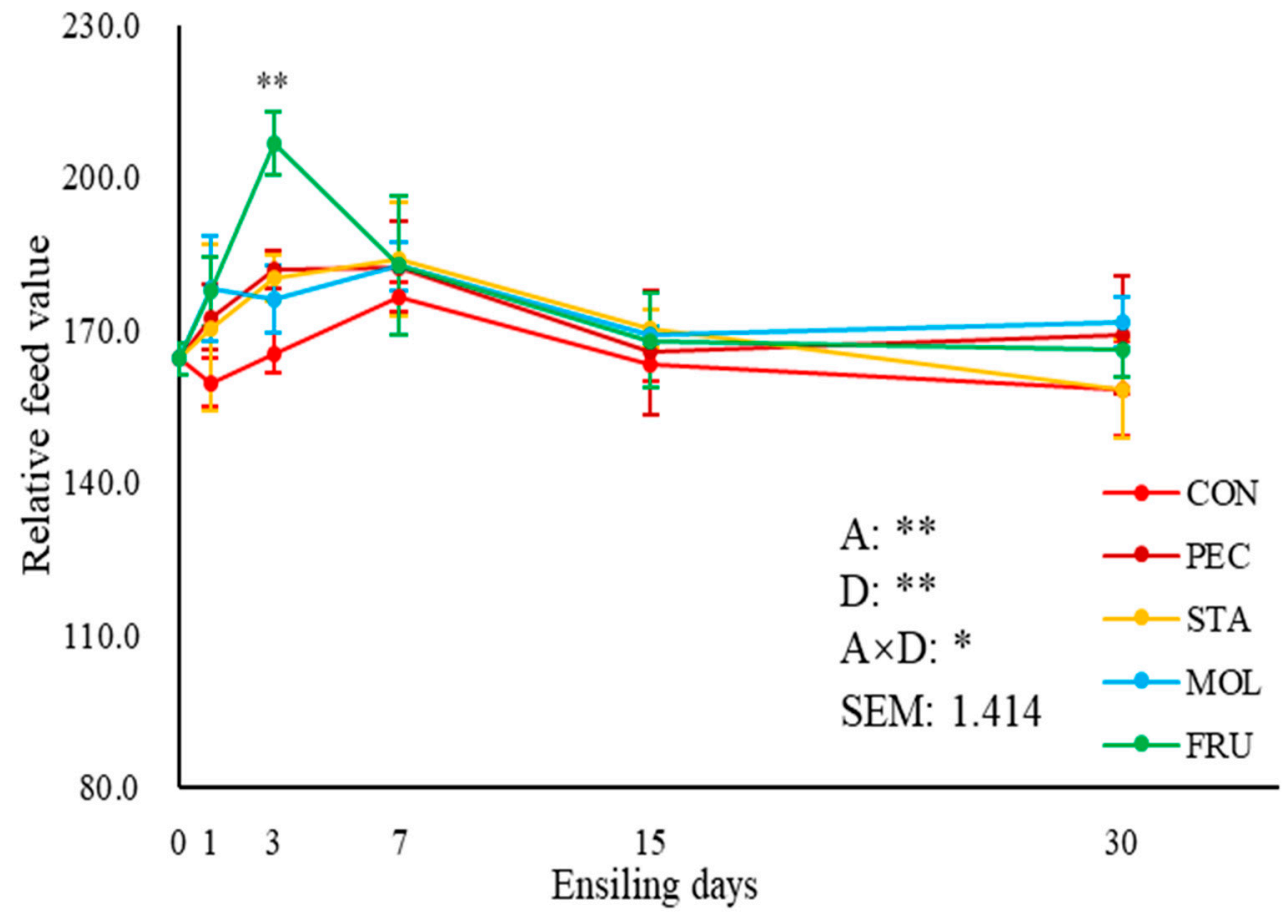

Figure 5. Effect of additives on the relative feed value (RFV) during ensiling of alfalfa. CON, control; PEC, pectin; STA, starch; MOL, molasses; FRU, fructose. A denotes significance of additives; $\mathrm{D}$, denotes significance of ensiling days; $\mathrm{A} \times \mathrm{D}$ denotes the interactive effect between additives and ensiling days. SEM, standard error of means. The asterisks $\left.{ }^{*} p \leq 0.05 ;{ }^{* *} p \leq 0.01\right)$ indicate the significance of additives and ensiling days and their interaction effects, and the difference at the specified ensiling day. 


\subsection{Analysis of Correlation between WSC and the Fermentation Profiles and Chemical Compositions}

To determine the relationship between WSC content and fermentation profile and chemical compositions, Spearman correlation analysis was performed. Throughout the ensiling process, $\mathrm{pH}$ was positively correlated with the WSC content and negatively correlated with the PA and AN contents and Fleig's point (Figure 6). In other words, the $\mathrm{pH}$ decreased as the WSC content decreased. However, at $30 \mathrm{~d}$ of ensiling, the WSC content was positively correlated with Fleig's point and negatively correlated with the $\mathrm{pH}$ (Figure 7). The DM content and RFV tended to positively correlate with the WSC content, and the NDF and ADF contents tended to negatively correlate with the WSC content.

\section{correlation test}

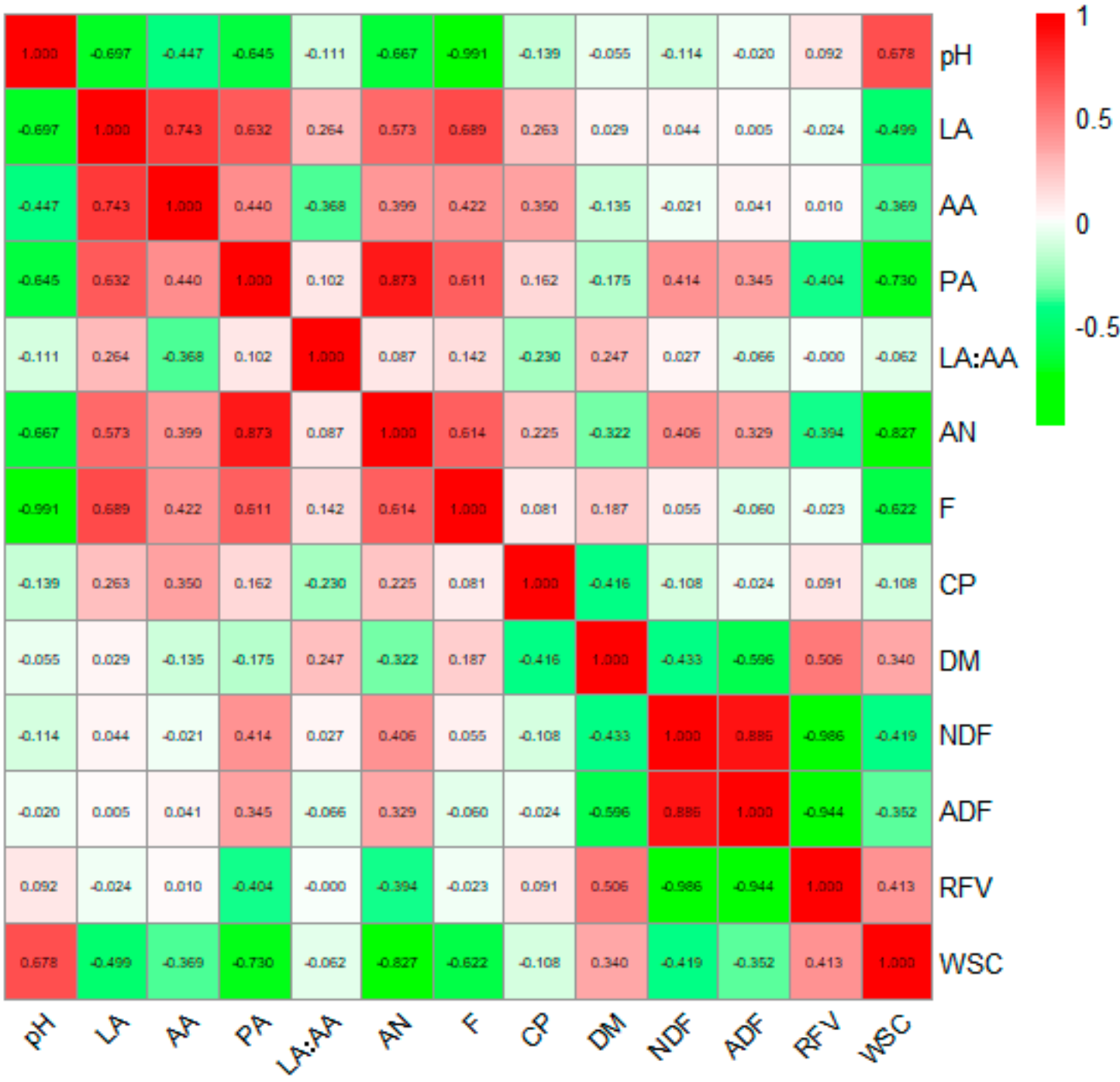

Figure 6. Pearson correlation between the fermentation and chemical indexes of alfalfa silages throughout the ensiling period. LA, lactic acid; AA, acetic acid; PA, propionic acid; LA:AA, lactic acid: acetic acid ratio; AN, ammonia nitrogen; F, Fleig's point; $\mathrm{CP}$, crude protein; $\mathrm{DM}$, dry matter; NDF, neutral detergent fiber; $\mathrm{ADF}$, acid detergent fiber; RFV, relative feed value; WSC, water-soluble carbohydrates. The number in each square represents the correlation extent; the color represents significant correlation $(p<0.05)$, the deeper the color of the square is, the more significant the correlation. The red color means a positive correlation, and the green color means a negative correlation. 


\section{correlation test}

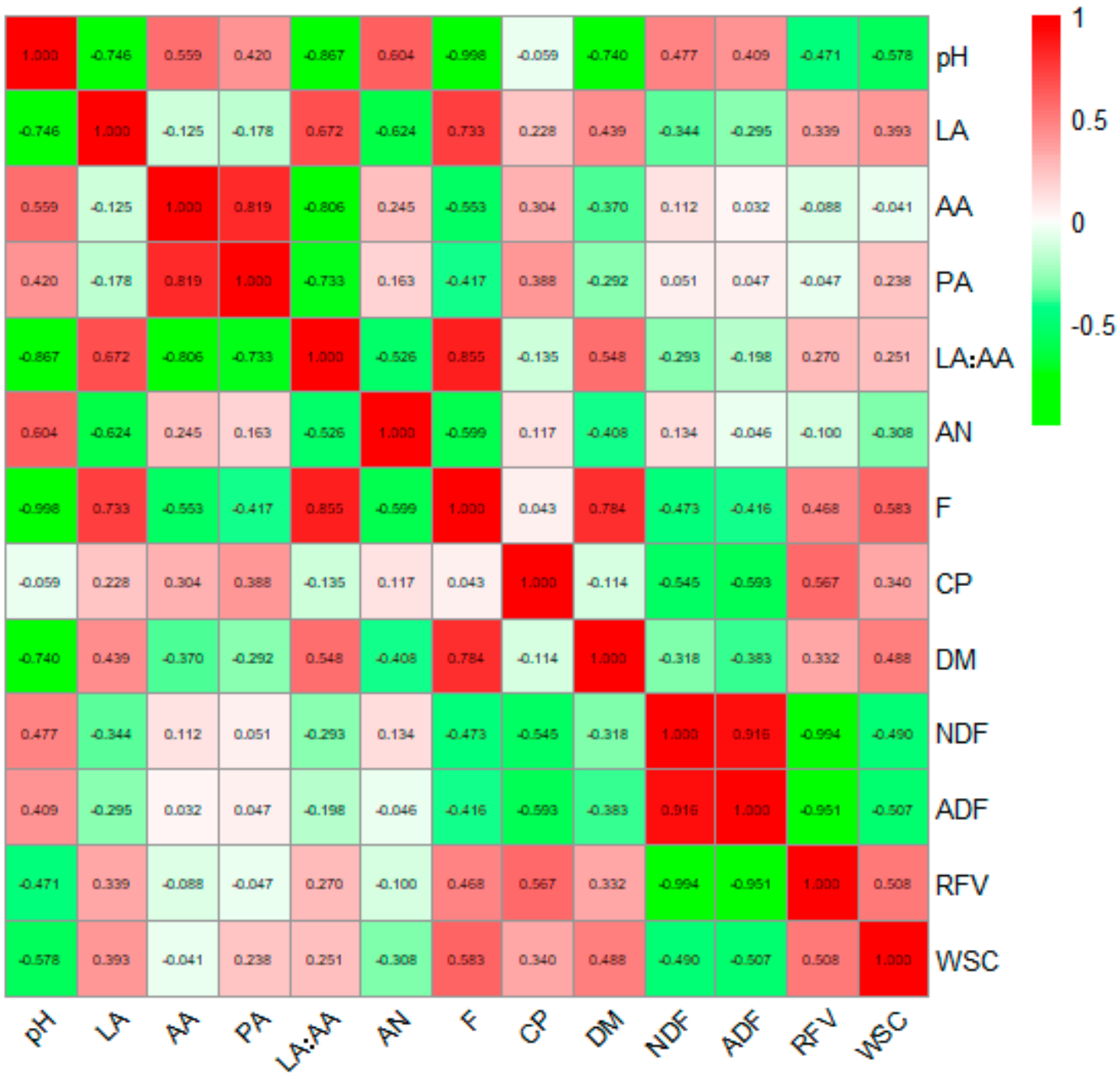

Figure 7. Pearson correlation between the fermentation and chemical indexes of alfalfa silages at $30 \mathrm{~d}$ of ensiling. LA, lactic acid; AA, acetic acid; PA, propionic acid; LA:AA, lactic acid: acetic acid ratio; AN, ammonia nitrogen; F, Fleig's point; CP, crude protein; DM, dry matter; NDF, neutral detergent fiber; ADF, acid detergent fiber; RFV, relative feed value; WSC, water-soluble carbohydrates. The number in each square represents the correlation extent; the color represents significant correlation $(p<0.05)$, the deeper the color of the square is, the more significant the correlation. The red color means a positive correlation, and the green color means a negative correlation.

\section{Discussion}

Various additives have been applied to alfalfa to improve its fermentation quality [6-15]. In a recent study, the main additive $L$. plantarum was applied to alfalfa because few LAB are attached to alfalfa surfaces to support fermentation [2]. However, alfalfa also lacks of a WSC substrate that is sufficient to sustain the fermentation for LAB during the ensiling [26]. The main ingredient of MOL is sucrose, which is widely applied to alfalfa silage to improve fermentation quality $[27,28]$. In our research, MOL was not found to be the optimal additive to improve alfalfa silage fermentation. Compared with CON and STA, MOL exhibited a lower $\mathrm{pH}$, and higher LA and Fleig's points during the ensiling period. The result was similar to that of Yuan et al. [29], who reported that alfalfa treated with MOL resulted in a lower $\mathrm{pH}$ than that of the control. It was also reported that adding MOL lowered the quality of both wilted and fresh lucerne silage [30]. However, MOL exhibited a higher $\mathrm{pH}$ than FRU and PEC and a lower LA content and Fleig's point during the ensiling period. 
Li et al. [31] reported that the application of sucrose decreased the $\mathrm{pH}$ and AA content and increased the LA and ethanol contents of alfalfa silages, which resulted in high-quality alfalfa silage. It was revealed that lucerne treated with fresh or frozen MOL-based prefermented juice had an increased fermentation quality and organic matter digestibility [28]. $\mathrm{Li}$ et al. [31] also reported that the application of sucrose or organic acids improved the quality of alfalfa silage.

The FRU and PEC treatments exhibited lower $\mathrm{pH}$ than the other treatments from $3 \mathrm{~d}$ to the end of the ensiling period in the present study. This result was consistent with that of Wang et al. [32], who reported that the fermentation quality was improved of alfalfa silage upon the application of PEC and FRU treatments. One possible reason was that FRU and PEC increased the carbohydrate for LAB fermentation, and the lower $\mathrm{pH}$ condition inhibited the growth of Clostridium and Escherichia coli, which are not desirable for the fermentation process. It was reported that PEC degradation is an important factor for alfalfa fermentation because of the resulting diverse bacterial community [33], and the application of PEC and pectinase lowered the $\mathrm{pH}, \mathrm{AA}, \mathrm{PA}$ and $\mathrm{AN}$ contents and increased the LA content. Leuconostoc abundance was higher upon PEC treatment and the application of pectinase resulted in higher Bacillus, Aeromonas, and Curvibacter abundances. These results show that PEC and pectinase improved the fermentation quality of alfalfa silage. L. plantarum is typically applied to alfalfa to improve its fermentation quality. Zhao et al. [6] reported that $L$. plantarum ZZU203, which was selected because of its advanced structural carbohydrate metabolites, resulted in higher DM, LA, AA, and WSC concentrations, lower AN and NDF concentrations, and aerobic bacterial and Clostridium counts in silage. However, FRU and PEC treatments exhibited advanced effects on fermentation quality in the present study. FRU and PEC exist in fruit juice and in citrus and apple peels, respectively; therefore, it is possible to apply fruit juice and citrus or apple peels to alfalfa to improve its fermentation quality. These additives not only can improve fermentation quality but also may be one of high-quality forages to feed ruminants $[16,33]$.

\section{Conclusions}

The addition of FRU and PEC effectively improved the fermentation quality of alfalfa silage, reduced the $\mathrm{pH}$ and $\mathrm{PA}$ and $\mathrm{AN}$ contents, as well as increased the contents of LA, LA:AA ratio, and Fleig's point at $60 \mathrm{~d}$ ensiling day. Thus, FRU and PEC or their related agricultural byproducts may offer alternative additives to improve the fermentation profile of alfalfa silage.

Author Contributions: For research articles with five authors. Conceptualization, R.G., B.W., and Z.Y.; methodology, R.G.; software, R.G.; validation, B.W., T.J., and Z.Y.; formal analysis, R.G.; investigation, R.G., Y.L., and B.W.; resources, Z.Y.; data curation, R.G.; writing-original draft preparation, R.G.; writing—review and editing, R.G.; visualization, R.G.; supervision, Z.Y.; project administration, Z.Y.; funding acquisition, Z.Y. All authors have read and agreed to the published version of the manuscript.

Funding: This research was funded by the Key Technologies Research and Demonstration for Efficient Utilization of Modern Artificial Grassland, grant number 2017BY082, Demonstration Project of Exploitation and Utilization of High-Quality Green and Rough Feed Resources, grant number 16200157; China Forage and Grass Research System, grant number CARS-34.

Institutional Review Board Statement: Not applicable.

Informed Consent Statement: Informed consent was obtained from all subjects involved in the study.

Data Availability Statement: The data presented in this study are available on request from the corresponding author.

Conflicts of Interest: The authors declare no conflict of interest. 


\section{References}

1. Coblentz, W.K.; Muck, R.E.; Borchardt, M.A.; Spencer, S.K.; Jokela, W.E.; Bertram, M.G.; Coffey, K.P. Effects of dairy slurry on silage fermentation characteristics and nutritive value of alfalfa. J. Dairy Sci. 2014, 97, 7197-7211. [CrossRef]

2. Kung, L.; Taylor, C.C.; Lynch, M.P.; Neylon, J.M. The effect of treating alfalfa with Lactobacillus buchneri 40,788 on silage fermentation, aerobic stability, and nutritive value for lactating dairy cows. J. Dairy Sci. 2003, 86, 336-343. [CrossRef]

3. Dewhurst, R.J.; Fisher, W.J.; Tweed, J.K.; Wilkins, R.J. Comparison of grass and legume silages for milk production. 1. Production responses with different levels of concentrate. J. Dairy Sci. 2003, 86, 2598-2611. [CrossRef]

4. Mcdonald, P.; Henderson, A.R. Buffering Capacity of Herbage Samples as a Factor in Ensilage. J. Sci. Food Agric. 1962, 13, 395-400. [CrossRef]

5. Muck, R.E. Silage microbiology and its control through additives. Rev. Bras. Zootec. 2010, 39, 183-191. [CrossRef]

6. Zhao, S.S.; Wang, Y.P.; Yang, F.Y.; Wang, Y.; Zhang, H. Screening a Lactobacillus plantarum strain for good adaption in alfalfa ensiling and demonstrating its improvement of alfalfa silage quality. J. Appl. Microbiol. 2020, 129, 233-242. [CrossRef]

7. Wu, Z.; Xu, S.; Yun, Y.; Jia, T.; Yu, Z. Effect of 3-Phenyllactic Acid and 3-Phenyllactic Acid-Producing Lactic Acid Bacteria on the Characteristics of Alfalfa Silage. Agriculture 2019, 10, 10. [CrossRef]

8. Su, R.N.; Ni, K.K.; Wang, T.W.; Yang, X.P.; Zhang, J.; Liu, Y.Y.; Shi, W.X.; Yan, L.; Jie, C.; Zhong, J. Effects of ferulic acid esteraseproducing Lactobacillus fermentum and cellulase additives on the fermentation quality and microbial community of alfalfa silage. PeerJ 2019, 7. [CrossRef]

9. Chen, L.; Dong, Z.; Li, J.; Shao, T. Ensiling characteristics, in vitro rumen fermentation, microbial communities and aerobic stability of low-dry matter silages produced with sweet sorghum and alfalfa mixtures. J. Sci. Food Agric. 2019, 99, 2140-2151. [CrossRef]

10. Agarussi, M.C.N.; Pereira, O.G.; da Silva, V.P.; Leandro, E.S.; Ribeiro, K.G.; Santos, S.A. Fermentative profile and lactic acid bacterial dynamics in non-wilted and wilted alfalfa silage in tropical conditions. Mol. Biol. Rep. 2019, 46, 451-460. [CrossRef]

11. Zhang, Q.; Yu, Z.; Wang, X.G.; Tian, J.P. Effects of inoculants and environmental temperature on fermentation quality and bacterial diversity of alfalfa silage. Anim. Sci. J. 2018, 89, 1085-1092. [CrossRef]

12. Tao, X.X.; Chen, S.F.; Zhao, J.; Wang, S.R.; Dong, Z.H.; Li, J.F.; Sun, F.X.; Shao, T. Effects of citric acid residue and lactic acid bacteria on fermentation quality and aerobic stability of alfalfa silage. Ital. J. Anim. Sci. 2020, 19, 744-752. [CrossRef]

13. Ke, W.C.; Ding, W.R.; Ding, L.M.; Xu, D.M.; Zhang, P.; Li, F.H.; Guo, X.S. Influences of malic acid isomers and their application levels on fermentation quality and biochemical characteristics of alfalfa silage. Anim. Feed Sci. Technol. 2018, 245, 1-9. [CrossRef]

14. Ke, W.C.; Ding, W.R.; Xu, D.M.; Ding, L.M.; Zhang, R.; Li, F.D.; Guo, X.S. Effects of addition of malic or citric acids on fermentation quality and chemical characteristics of alfalfa silage. J. Dairy Sci. 2017, 100, 8958-8966. [CrossRef]

15. Tian, J.P.; Li, Z.Z.; Yu, Z.; Zhang, Q.; Li, X.J. Interactive effect of inoculant and dried jujube powder on the fermentation quality and nitrogen fraction of alfalfa silage. Anim. Sci. J. 2017, 88, 633-642. [CrossRef]

16. Wang, B.; Mao, S.Y.; Yang, H.J.; Wu, Y.M.; Wang, J.K.; Li, S.L.; Shen, Z.M.; Liu, J.X. Effects of alfalfa and cereal straw as a forage source on nutrient digestibility and lactation performance in lactating dairy cows. J. Dairy Sci. 2015, 98, 719. [CrossRef]

17. Liu, J.; Pu, Y.Y.; Xie, Q.; Wang, J.K.; Liu, J.X. Pectin Induces an in vitro Rumen Microbial Population Shift Attributed to the Pectinolytic Treponema Group. Curr. Microbiol. 2015, 70, 67-74. [CrossRef]

18. Besharati, M.; Shafipour, N.; Abdi, E.; Nemati, Z. Effects of supplementation alfalfa silage with molasses, orange pulp and Lactobacillus buchneri on in vitro dry matter digestibility and gas production. J. Biosci. Biotechnol. 2017, 6, 43-47.

19. Broderick, G.A.; Kang, J.H. Automated simultaneous determination of ammonia and total amino acids in ruminal fluid and in vitro media. J. Dairy Sci. 1980, 63, 64-75. [CrossRef]

20. He, L.; Zhou, W.; Wang, Y.; Wang, C.; Chen, X.; Zhang, Q. Effect of applying lactic acid bacteria and cellulase on the fermentation quality, nutritive value, tannins profile and in vitro digestibility of Neolamarckia cadamba leaves silage. J. Anim. Physiol. Anim. Nutr. 2018, 102, 1429-1436. [CrossRef]

21. AOAC. Official Methods of Analysis; AOAC: Arlington, VA, USA, 1990.

22. Van Soest, P.J.; Robertson, J.B.; Lewis, B.A. Methods for dietary fiber, neutral detergent fiber, and nonstarch polysaccharides in relation to animal nutrition. J. Dairy Sci. 1991, 74, 3583-3597. [CrossRef]

23. Murphy, R.P. A method for the extraction of plant samples and the determination of total soluble carbohydrates. J. Sci. Food Agric. 2010, 9. [CrossRef]

24. Kilic, A. Silo Feed (Instruction, Education and Application Proposals); Bilgehan Press: Izmir, Turkey, 1986.

25. Jeranyama, P.; Garcia, A.D. Understanding Relative Feed Value (RFV) and Relative Forage Quality (RFQ); SDSU: Brookings, SD, USA, 2004.

26. Guo, G.; Yuan, X.J.; Li, L.X.; Wen, A.Y.; Shao, T. Effects of fibrolytic enzymes, molasses and lactic acid bacteria on fermentation quality of mixed silage of corn and hulless-barely straw in the Tibetan Plateau. Grassl. Sci. 2014, 60, 240-246. [CrossRef]

27. Chen, L.; Guo, G.; Yuan, X.; Zhang, J.; Li, J.; Shao, T. Effects of applying molasses, lactic acid bacteria and propionic acid on fermentation quality, aerobic stability and in vitro gas production of total mixed ration silage prepared with oat-common vetch intercrop on the Tibetan Plateau. J. Sci. Food Agric. 2016, 96, 1678-1685. [CrossRef]

28. Denek, N.; Can, A.; Avci, M.; Aksu, T.; Durmaz, H. The effect of molasses-based pre-fermented juice on the fermentation quality of first-cut lucerne silage. Grass Forage Sci. 2011, 66, 243-250. [CrossRef] 
29. Yuan, X.; Wen, A.; Wang, J.; Guo, G.; Desta, S.T.; Shao, T. Effects of ethanol, molasses and Lactobacillus plantarum on the fermentation quality, in vitro digestibility and aerobic stability of total mixed ration silages in the Tibetan plateau of China. Anim. Sci. J. 2016, 87, 681-689. [CrossRef]

30. Hashemzadeh-Cigari, F.; Khorvash, M.; Ghorbani, G.R.; Taghizadeh, A. The effects of wilting, molasses and inoculants on the fermentation quality and nutritive value of lucerne silage. S. Afr. J. Anim. Sci. 2011, 41, 377-388. [CrossRef]

31. Li, P.; Ji, S.R.; Hou, C.; Tang, H.Y.; Wang, Q.; Shen, Y.X. Effects of chemical additives on the fermentation quality and N distribution of alfalfa silage in south of China. Anim. Sci. J. 2016, 87, 1472-1479. [CrossRef]

32. Wang, B.; Gao, R.; Wu, Z.; Yu, Z. Functional Analysis of Sugars in Modulating Bacterial Communities and Metabolomics Profiles of Medicago sativa Silage. Front. Microbiol. 2020, 11, 641. [CrossRef]

33. Wang, B.; Sun, Z.Q.; Yu, Z. Pectin Degradation is an Important Determinant for Alfalfa Silage Fermentation through the Rescheduling of the Bacterial Community. Microorganisms 2020, 8, 488. [CrossRef] 